\title{
Survey of cyclopiazonic acid contamination in corn from China and Southeast Asian countries
}

\author{
Yoshiki HaYASH and Takumi YoshIZAWA* \\ Department of Biochemistry and Food Science, Faculty of Agriculture, Kagawa University \\ (M iki, Kagawa 761-0795, Japan)
}

\begin{abstract}
Summary
Natural incidence of cyclopiazonic acid (CPA) in corn from the southern part of China and Southeast Asian countries including Indonesia, Thailand, and the Philippines, was sur veyed using a combination of a clean-up procedure consisting of diethyl ether liquid-liquid extraction and HPLC-UV analysis. Out of 99 corn samples analyzed, 15 samples ( $15 \%$ were contaminated with CPA. The detected concentration of CPA ranged from 27 to $1510 \mu \mathrm{g} / \mathrm{kg}$, with all CPA positive samples contaminated with aflatoxin $B_{1}\left(A F B_{1}\right)$. It was noteworthy that the high level of CPA together with $A_{F} B_{1}$ over $1000 \mu \mathrm{g} / \mathrm{kg}$ was found in the samples intended for human consumption from China and the Philippines.
\end{abstract}

Key words : cyclopiazonic acid, aflatoxins, corn, China, Southeast Asia, Thailand, Indonesia, Philippines

(Received: M ay 27, 2004, Revised \& Accepted: J une 28, 2004)

\section{Introduction}

Cyclopiazonic acid (CPA) is a toxic secondary metabolite produced by several species of Penicillium and Aspergillus, including P. cyclopium ${ }^{1)}$, P. camemberti ${ }^{2)}$, A. oryzae ${ }^{3}$, A. tamarii ${ }^{4}$, and A. flavus ${ }^{5}$. These fungi are widely distributed in nature and the natural occurrence of CPA has been reported in corn $n^{6}$ and peanuts ${ }^{7}$, often together with aflatoxins (AF).

Both CPA and AF have been shown to cause health problems in animals and humans. Toxicosis resulting from consumption of CPA-contaminated commodities has not been proven, but has been implicated as the causative agent in a human intoxication known as 'Koudua poisoning' involving consumption of contaminated millet ${ }^{8)}$. In addition, CPA was also suggested to be responsible for the outbreak termed 'Turkey $X$ disease' in which AF were strongly implicated ${ }^{91}$.

AF have been classified as Class I human carcinogens ${ }^{10}$ and well recognized as serious food contaminants in the tropics more than in temperate zones of the world. Contamination levels of AF in corn as a staple food of many temperate countries and other corn-producing countries have been reported. Furthermore, natural co-occurrence of both AF and Fusarium toxins including fumonisins (FM), nivalenol and zearalenone has been reported in corn from China ${ }^{111}$ and Southeast Asian

\footnotetext{
${ }^{*}$ Corresponding author: Takumi YosHIZAWA
} 
countries ${ }^{12-14}$. However, few surveys have been conducted to determine CPA contamination in agricultural commodities from Southeast Asian countries. Contamination level of CPA in corn as a staple food in these countries has not been well studied, and relevant data is very limited.

Reports on the natural occurrence of CPA in agricultural commodities are very limited. Gallagher et al. (1978) found CPA in AF-contaminated North American corn samples ${ }^{6}$. U rano et al. (1992) has studied the AF and CPA contamination in corn and peanuts from U.S.A. ${ }^{15,16)}$. Only one report by Widiastuti et al. (1988) is available on tropical crops; this study analyzed CPA in Indonesian corn by thin layer chromatography ${ }^{17)}$. In these reports, toxic solvents such as chloroform and dichloromethane were used as extraction and clean-up solvents.

Recently, we developed a method for the determination of CPA in corn using a clean-up procedure consisting of liquid-liquid extraction with diethyl ether coupled with HPLC-UV ${ }^{18}$. In the present study, we surveyed the CPA contamination levels in corn from the southern part of China and Southeast Asian countries using this method. Based on results, the simultaneous occurrence of CPA and AF was discussed. This is the first report of the natural occurrence of CPA in corn for human consumption from China and the Philippines.

\section{Materials and Methods}

Corn Samples Twenty samples of yellow corn kernel (more than $200 \mathrm{~g}$ each) intended for human consumption were collected in 1998 from Chongzuo County in Guanxi Province, in the southern part of China, an area with a high incidence of human primary hepatocellular carcinoma. Twelve samples of Indonesian corn (more than $100 \mathrm{~g}$ each) and 28 samples of Thai corn (more than $100 \mathrm{~g}$ each), intended for animal and human consumption, were collected in 1992 and 1993, respectively. Thirtynine samples of Philippine corn (more than $100 \mathrm{~g}$ each) intended for human consumption were collected in 1997 and 1998; seven of these samples were white corn kernels and 32 samples were yellow corn kernels and corn grits. These samples were previously analyzed for AF in our laborator $\mathrm{y}^{11,12,19)}$ and were stored in zip-lock plastic bags at $-20{ }^{\circ} \mathrm{C}$ until needed.

Extraction and clean-up Extraction and clean-up were conducted following the procedure reported by Hayashi and Yoshizawa. ${ }^{18)}$ Briefly, ground samples (15 g each) were extracted with acetonitrile $-1 \%$ sodium bicarbonate $(7: 3, \mathrm{v} / \mathrm{v}, 50 \mathrm{ml})$ and centrifuged at $1,400 \times \mathrm{g}$ for $5 \mathrm{~min}$. The supernatant extract $(30 \mathrm{ml})$ was mixed with $0.05 \mathrm{~mol} / \mathrm{L}$ lead acetate $(60 \mathrm{ml})$ and filtered using an Advantec GA-55 glass filter (Advantec Toyo Kaisya, Ltd., Tokyo, Japan). The filtrate (40 ml) was adjusted to $\mathrm{pH} 2$ by adding $0.5 \mathrm{~mol} / \mathrm{L} \mathrm{HCl}$ (ca. $5.5 \mathrm{ml}$ ), and partitioned twice with diethyl ether ( 25 $\mathrm{ml}$ ). As an additional clean-up step, the combined diethyl ether extract (ca. $50 \mathrm{ml}$ ) was extracted twice with $5 \%$ sodium bicarbonate $(20 \mathrm{ml}$ ). The combined aqueous layer ( $\mathrm{ca} .40 \mathrm{ml}$ ) was acidified to $\mathrm{pH} 2$ with $6 \mathrm{~mol} / \mathrm{L} \mathrm{HCl}$, which was partitioned twice with diethyl ether $(25 \mathrm{ml})$. Finally, the combined diethyl ether was evaporated in vacuo and dissolved in methanol $-1 \mathrm{~m} \mathrm{~mol} / \mathrm{L}$ zinc sulfate $(85: 15, \mathrm{v} / \mathrm{v}$, $0.5 \mathrm{ml}$ ). An aliquot ( $10 \mu \mathrm{l}$ ) of the sample extract was injected into the HPLC column.

HPLC analysis The quantification of CPA in corn samples was performed by HPLC with UV detection under the following conditions: Shimadzu SCL-6A system connected to a Shimadzu SPDM 10AVP photodiode array detector interfaced with a Shimadzu CBM-10A communications bus 
module and a Shimadzu CLASS-LC10 model FM V-6300 DX 2c computer; reversed phase column TSK-gel ODS-80TM CTR, $5 \mu \mathrm{m}, 100 \times 4.6 \mathrm{~mm}$, TOSOH Co., Tokyo, Japan); oven temperature - $40{ }^{\circ} \mathrm{C}$; wavelength - $279 \mathrm{~nm}$; methanol - water $(85: 15, \mathrm{v} / \mathrm{v})$ as mobile phase $A$; methanol $-4 \mathrm{~m} \mathrm{~mol} / \mathrm{L}$ zinc sulfate $(85: 15, \mathrm{v} / \mathrm{v})$ as mobile phase $B$; a linear gradient from mobile phase $A$ to mobile phase $B$ in 10 $\mathrm{min}$ at a flow rate of $1.2 \mathrm{ml} / \mathrm{min}$. The limit of quantification in corn was $25 \mathrm{ng} \mathrm{CPA} / \mathrm{g}$. The average recoveries from triplicate corn samples spiked with 25, 50, 100 and $200 \mathrm{ng}$ CPA/g were 64.7, 68.5, 74.6 and $75.4 \%$ respectively.

\section{Results and Discussion}

A typical HPLC chromatogram of CPA in a naturally contaminated corn sample is shown in Fig. 1. The presence of CPA in corn samples was confirmed by HPLC-photodiode array detection as shown in Fig. 2. Incidence and concentration of CPA in corn from China and Southeast Asian countries including Thailand, Indonesia, and the Philippines are summarized in Table 1. Out of 99 corn samples surveyed, 15 samples ( $15 \%$ were contaminated with CPA: China (7), Thailand (1), Indonesia (1), and the Philippines (6). The detected concentration of CPA ranged from 27 to 1510 $\mu \mathrm{g} / \mathrm{kg}$ (mean, $53 \mu \mathrm{g} / \mathrm{kg}$ ).

Occurrence of CPA in corn from China and the Philippines Natural co-occurrence of CPA and $A F$ in corn samples intended for human consumption from China ${ }^{11)}$ and the Philippines ${ }^{19)}$ are summarized in Table 2. Data of $\mathrm{AFB}_{1}$ contamination were cited from our previous publications ${ }^{11,12,19)}$.

CPA was detected in 7 samples (35\%) of Chinese corn with concentration ranging from 42 to $1220 \mu \mathrm{g} / \mathrm{kg}$ (mean, $129 \mu \mathrm{g} / \mathrm{kg}$ ). The highest level of CPA (1220 $\mu \mathrm{g} / \mathrm{kg}$ ) was found in the sample (CZ98-C10) contaminated with the highest level of $A_{F B}(2496 \mu \mathrm{g} / \mathrm{kg})$. Li et al ${ }^{11}{ }^{11}$ reported on the high incidence of simultaneous contamination with $A F$ and Fusarium toxins such as $F M$ in these corn samples. In the case of the Philippine samples, 6 (15\%) were found to be naturally contaminated with
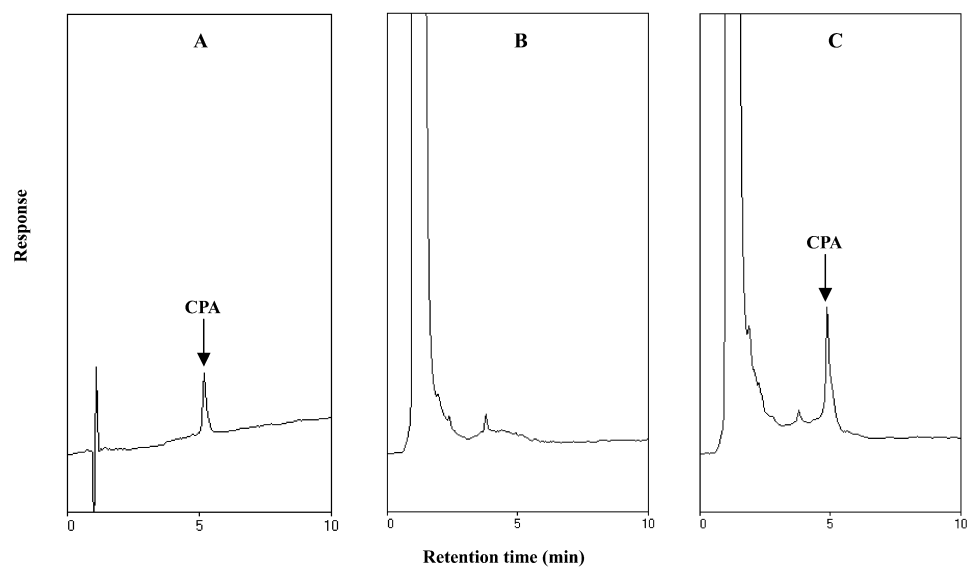

Fig. 1. HPLC chromatograms of CPA in Chinese corn.
A) CPA standard (10 ng)
B) CPA-free corn sample (CZ-98-12)
C) CPA-contaminated corn (CZ-98-16, $335 \mu \mathrm{g} / \mathrm{kg}$ ) 


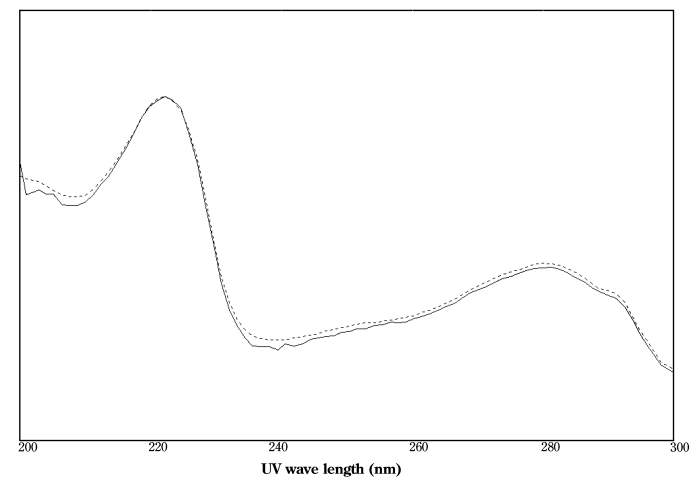

Fig. 2. UV spectra of CPA obtained from HPLC-photodiode array analysis. CPA in a contaminated Chinese corn sample (CZ-98-16) CPA standard

Table 1. Incidence and concentration of CPA in corn intended for human consumption from China and the Philippines

\begin{tabular}{lcccc}
\hline & & \multicolumn{3}{c}{ CPA } \\
\cline { 3 - 5 } Country & No. of samples & Detected & \multicolumn{2}{c}{ Concentration, $\mu \mathrm{g} / \mathrm{kg}$} \\
\cline { 3 - 5 } & 20 & $7(35)$ & M ean & Range \\
\hline China & 28 & $1(4)$ & 429 & $42-1220$ \\
Thailand & 12 & $1(8)$ & 63 & 42 \\
Indonesia & 39 & $6(15)$ & 69 & 63 \\
Philippines & 99 & $15(15)$ & 53 & $27-1510$ \\
\hline Total & & &
\end{tabular}

Table 2. Natural co-occurrence of CPA and AF in corn samples intended for human consumption from China and the Philippines*1

\begin{tabular}{lllrrr}
\hline \multirow{2}{*}{ Country } & & & \multicolumn{3}{c}{ Concentration, $\mu \mathrm{gg} / \mathrm{kg}$} \\
\cline { 3 - 6 } China & Sample code & Location & CPA & AFB $_{1}$ & AFB $_{2}$ \\
& CZ-98-C6 & Tiaiping & 72 & 698 & 111 \\
& CZ-98-C8 & Tiaiping & 129 & 103 & 11 \\
& CZ-98-C10 & Tiaiping & 1220 & 2496 & 320 \\
& CZ-98-C11 & Tiaiping & 42 & 185 & 29 \\
& CZ-98-C13 & Madalu & 288 & 2121 & 281 \\
& CZ-98-C16 & Nalong & 335 & 150 & 21 \\
& CZ-98-C20 & Zuozhou & 52 & 290 & 55 \\
& CW 6f & Iloilo & 27 & 10 & 9 \\
& CW Ba & Metro Manila & 29 & 369 & $-* 2$ \\
& CW 6b & Iloilo & 63 & 2 & - \\
& CW 6d & Iloilo & 76 & 44 & - \\
& CW 6a & Iloilo & 210 & 319 & - \\
& CW 6C & Iloilo & 1510 & 1215 & 10 \\
\hline
\end{tabular}

${ }^{* 1}$ Data of $A F B_{1}$ and $A F B_{2}$ contamination were cited from previous publications: China $^{11)}$ and the Philippines ${ }^{19)}$.

*2 $\mathrm{N}$ ot detected 
CPA, with levels ranging from 27 to $1510 \mu \mathrm{g} / \mathrm{kg}$ (mean, $69 \mu \mathrm{g} / \mathrm{kg}$ ). The highest level of CPA (1510 $\mu \mathrm{g} / \mathrm{kg}$ ) was also found in the sample (CW $6 \mathrm{c}$ ) contaminated with the highest level of $A F B_{1}(1220$ $\mu \mathrm{g} / \mathrm{kg})^{19}$. The co-incidence of CPA and AF in yellow corn was higher than that in white corn from both China and the Philippines (data not shown).

It is noteworthy that the co-occurrence of $C P A$ and $A F B_{1}$ at levels over $1000 \mu \mathrm{g} / \mathrm{kg}$ was found in the samples intended for human consumption from China and the Philippines. All CPA positive samples were contaminated with $\mathrm{AFB}_{1}$; $\mathrm{CPA}$ was not found in non-AF contaminated samples. There was no quantitative correlation between $C P A$ and $A F B_{1}$ concentrations.

Occurrence of CPA in corn from Thailand and Indonesia Among 28 Thai corn and 12 Indonesian corn samples analyzed, one sample each was contaminated with CPA at a level of 42 $\mu \mathrm{g} / \mathrm{kg}$ (Thai corn) and $63 \mu \mathrm{g} / \mathrm{kg}$ (Indonesian corn); these samples were co-contaminated with $\mathrm{AFB}_{1}$ at levels of $84 \mu \mathrm{g} / \mathrm{kg}$ and $65 \mu \mathrm{g} / \mathrm{kg}^{12}$, respectively. Because the occurrence of CPA in Thai and Indonesian corn samples was lower than those from China and the Philippines, it is necessary to conduct further studies in the former countries.

Widiastuti et al. ${ }^{17)}$ reported heavy contamination of Indonesian corn with CPA at levels ranging from 30 to $9220 \mu \mathrm{g} / \mathrm{kg}$ together with $\mathrm{AFB}_{1}$. However, as the quantification of CPA was carried out by thin layer chromatography, those data should be interpreted with caution. Goto et al. ${ }^{20)}$ reported that 21 out of 22 isolates of $A$. flavus from agricultural commodities and soil from Indonesia produced $C P A$, and 7 of these isolates produced $A F B_{1}$. There are well-defined species: $A$. flavus produces only $B$ group $A F\left(A F B_{1}, A F B_{2}\right)$ and sometimes $C P A$, while $A$. parasiticus produces both $B$ and $G$ group $A F$, but never $\mathrm{CPA}^{10)}$. However, this definition has been complicated by more recent taxonomic finding ${ }^{10}$. Therefore, in order to solve this problem, further continuous survey of mycotoxin contamination in agricultural commodities and mycological study on Asian tropical crops are important steps towards eliminating the risk of mycotoxin contamination.

It has long been recognized that mycotoxin contamination is a serious problem with detrimental effects on human and animal health and productivity, and serious trade and economic repercussions. However, apart from the survey of AF, there have been very few reports on the co-occurrence of Aspergillus toxins such as CPA. This is the first report of the natural occurrence of CPA in corn for human consumption from China and the Philippines.

In conclusion, the co-occurrence of CPA and AF in corn from the southern part of China and Southeast Asian countries was ascertained. Taking into consideration that high levels of CPA, i.e. over $1000 \mu \mathrm{g} / \mathrm{kg}$, was found together with high levels of $A F B_{1}$ in the samples intended for human consumption from the southern part of China and the Philippines, further continuous survey of mycotoxin contamination in agricultural commodities in these areas needs to be addressed in order to eliminate the risk of mycotoxin contamination.

\section{References}

1 ) Holzapfel, C. W.: Tetrahedron, 24, 2101-2119 (1968)

2 ) Still, P. E., Eckardt, C., Leistner, L.: Fleischwirtschaft, 58, 876-877 (1978)

3 ) Orth, R.: Ann. Nutr. Aliment, 31, 617-624 (1977) 
4 ) Dorner, J. W.: Appl. Environ. M icrobiol., 46, 1435-1437 (1983)

5 ) Luk, K. C., Kobbe, B., Townsend, J. M.: Appl. Environ. M icrobiol., 33, 211-212 (1987)

6 ) Gallagher, R. T., Richard, J., L., Stahr, H. M ., Cole, R. J.: M ycopathologia, 66, $31-36$ (1978)

7 ) Lansden, J. A.: Appl. Environ. Microbiol., 45, 766-769 (1983)

8 ) Rao, B. L., Husain, A.: M ycopathologia, 89, 177-180 (1985)

9 ) Cole, R. J.: M ycotoxin Res., 2, 3-7 (1986)

10) International Agency for Research on Cancer: IARC M onographs on the Evaluation of Carcinogenic Risk to Humans, Vol. 82, Some Traditional Herbal M edicines, Some M ycotoxins, Naphthalene and Styrene. pp. 171-300 (2002), IARC, L yon

11) Li, F. Q., Yoshizawa, T., Kawamura, O., Luo, X. Y., Li, Y. W.: J. Agric. Food Chem., 49, 4122-4126 (2001)

12) Yamashita, A., Yoshizawa, T., Aiura, Y., Sanchez, P. C., Dizon, E. I., Arim, R., H., Sardjono: Biosci. Biotech. Biochem., 59, 1804-1807 (1995)

13) Yoshizawa, T., Yamashita, A., Chokethaworn, N.: Food Addit. Contam., 13, 163-168 (1996)

14) Ali, N., Sardjono, Yamashita, A., Yoshizawa, T.: Food Addit. Contam., 15, 377-384 (1998)

15) Urano, T., Trucksess, M. W., M atusik, J., Dorner, J. W.: J. AOAC Int., 75, 319-322 (1992)

16) Urano, T., Trucksess, M. W., Beaver, R. W., Wilson, D. M., Dorner, J. W., Dowell, F. E.: J. AOAC Int., 75, 838-841 (1992)

17) Widiastuti, R., M aryam, R., Blaney, B. J., Stoltz, S., Stoltz, D. R.: M ycopathologia, 104, 153-156 (1988)

18) Hayashi, Y., Yoshizawa, T.: "N ew horizon of mycotoxicology for assuring food safety" (eds.Yoshizawa, $T$, Kumagai, S., Goto, T.), pp. 309-313 (2004), Jpn. Assoc. M ycotoxicol., Tokyo.

19) Arim, R.: Ph.D. Thesis, Ehime university, pp. 74-77 (2000)

20) Goto, T., Ginting, E., Antarlina, S. S., Utomo, J. S., Ito, Y., Nikkuni, S.: "M ycotoxin contamination: health risk and prevention project" (eds. Kumagai, S., Goto, T., Kawai, K., Takahashi, H., Yabe, K., Yoshizawa, T., Koga, H., Kamimura, H., Akao, M .), pp. 211-215 (1999), Jpn. Assoc. M ycotoxicol., Tokyo.

\section{中国及び東南アジア産トウモロコシのシクロピアゾン酸污染}

林 芳樹, 芳澤宅實: 香川大学農学部（761-0795 香川県木田郡三木町池戸)

中国南部 (広西省) の肝癌高発地域及び東南アジア (タイ, インドネシア, フィリピン) 産トゥモロコシ 99 検体のシクロピアゾン酸 (CPA) 污染を, 新規に考案した分析法により検討したところ, 15 検体に (15\%) にCPA が検出され，その污染濃度は 27-1510 $\mu \mathrm{g} / \mathrm{kg}$ であった。CPA が検出されたすべての検体からアフラ トキシン $B_{1}\left(A F B_{1}\right)$ が検出された. 特に, 中国産及びフィリピン産の食用トウモロコシの污染頻度が高く, $1000 \mu \mathrm{g} / \mathrm{kg}$ を超える濃度の CPA と AFB ${ }_{1}$ の同時污染であることが注目された.

キーワード：シクロピアゾン酸, アフラトキシン, トゥモロコシ, 中国, 東南アジア, タイ, インドネシア, フィリピン 